\title{
Climatic signal in annual growth variation of silver fir (Abies alba Mill.) and spruce (Picea abies Karst.) from the French Permanent Plot Network (RENECOFOR)
}

\author{
François LEBOURGEOIS*
}

UMR INRA-ENGREF 1092 - Laboratoire d'Étude des Ressources Forêt-Bois (LERFOB) - Équipe Écologie Forestière, 54042 Nancy Cedex, France

(Received 23 May 2006; accepted 13 October 2006)

\begin{abstract}
This paper explores the growth/climate relationships in earlywood, latewood and total ring-width chronologies of five Norway spruce (Picea abies) and six silver fir (Abies alba) stands sampled in the French permanent plot network (RENECOFOR) (327 trees). The relationships between climate and ring widths were analyzed using extreme growth years, simple correlations and response functions analysis (bootstrapped coefficients). Monthly climatic regressors were derived by a physiological water balance model that used daily climatic data and stand parameters to estimate soil water deficits. Pointer years underline the high sensitivity to winter frosts $(1956,1986)$ and exceptional annual droughts $(1962,1976,1991)$ for both species. For those years, growth variations were higher for Abies alba than for Picea abies. For each species, the climate information of tree ring series is not modified by local site characteristics (altitude, slope, aspect, soil water reserve). Moreover, strong specific differences appear among species. Earlywood and latewood spruce growth mainly depends on current summer soil water deficit conditions. For silver fir, winter and early summer temperatures, as well as the water supply of the previous year (August to October) play a major role for the production of earlywood, after which the current early summer water supply influences mainly latewood width.
\end{abstract}

Abies alba / Picea abies / tree ring / water balance / drought / pointer years / response functions

Résumé - Réponse au climat du sapin pectiné (Abies alba Mill.) et de l'épicéa commun (Picea abies Karst.) dans le Réseau National de suivi à long terme des Écosystèmes Forestiers (RENECOFOR). Cet article présente les relations entre le climat et les variations des largeurs du bois initial, du bois final et du cerne complet pour cinq peuplements d'épicéa commun (Picea abies) et six peuplements de sapin pectiné (Abies alba) échantillonnés dans le réseau national de suivi à long terme des écosystèmes forestiers (RENECOFOR) (327 arbres). L'effet du climat sur la largeur des cernes a été analysé à partir de l'étude des années caractéristiques et l'établissement des fonctions de réponse. Les régresseurs climatiques mensuels pris en compte sont issus d'un modèle de bilan hydrique à base écophysiologique qui utilise comme variables d'entrée des données météorologiques journalières et les caractéristiques du peuplement. Les années caractéristiques montrent la forte sensibilité aux froids extrêmes (1956, 1986) et aux sécheresses intenses $(1962,1976,1991)$ des deux espèces avec néanmoins des variations de croissance plus marquées pour le sapin pectiné. Pour chaque espèce, les caractéristiques écologiques locales (altitude, pente, exposition, etc.) ne modifient pas la réponse au climat. Cependant, le comportement des deux espèces apparaît très différent. Pour l'épicéa, la mise en place du bois initial et du bois final dépend essentiellement du déficit hydrique estival de l'année en cours. Pour le sapin, la largeur du bois initial dépend à la fois du régime thermique hivernal et du début d'été de l'année en cours et de la sécheresse de la fin de saison précédente (août à octobre). Par la suite, la sécheresse estivale de l'été en cours influence la mise en place du bois final.

Abies alba / Picea abies / cerne / bilan hydrique / sécheresse / année caractéristique / fonctions de réponse

\section{INTRODUCTION}

Silver fir (Abies alba Mill.) and Norway spruce (Picea abies [L.] Karst.) are widely distributed species in Europe and have proved to be important species for dendrochonological studies. In France, the natural distribution areas correspond to mountainous regions (Alps, Pyrenees, Vosges). In these contexts, natural mixed or pure coniferous forests cover a wide range of substrate, topographic and climatic conditions. The habitat of both species is quite comparable, but silver fir is absent at the upper level $[4,9,10,41,42,46]$. From an ecophysiological point of view, the shade tolerant silver fir species appears to be rather a more frost and drought-sensitive species than Norway spruce which behaves as a pioneer species [2,24].

\footnotetext{
* Corresponding author: lebourgeois@engref.fr
}

Over the last few decades, damage to coniferous ecosystems has occurred over many regions throughout Europe and France $[5,47]$. Sometimes, the symptoms can be explained by well-identified agents such as insect pests, fungal attack, mineral deficiency, etc. In addition, extreme climatic events (e.g. severe drought, winter or late frost) can play an important role in promoting growth decrease and forest decline $[3-6,10]$. In the context of climate change and of potential effects of the exceptional heat waves (such as that observed in 2003 throughout Europe [16]), questions are being raised concerning survival and growth of natural vegetation in response to changes in yearly weather conditions and/or extreme events [15]. Due to land abandonment, an important increase in the establishment of both species is observed in various mountainous regions nowadays. Thus, a better understanding 
Table I. Site description and characteristics of selected stands. Age at breast height, mean values (SD)/maximum. H and DBH = Tree height and diameter at breast height, mean values (SD). $\mathrm{N}=$ number of trees per hectare. LAI = Maximum Leaf Area Index. EW: Maximum Extractable Soil Water (mm).

\begin{tabular}{|c|c|c|c|c|c|c|c|c|c|c|c|c|}
\hline & Site code & Latitude & Longitude & $\begin{array}{l}\text { Alt. } \\
\text { (m) }\end{array}$ & $\begin{array}{c}\text { Slope } \\
(\%)\end{array}$ & Aspect & $\begin{array}{c}\text { Age } \\
\text { (years) }\end{array}$ & $\begin{array}{c}\mathrm{H} \\
(\mathrm{m})\end{array}$ & $\begin{array}{l}\text { DBH } \\
(\mathrm{cm})\end{array}$ & $\begin{array}{c}\mathrm{N} \\
(\mathrm{n} / \mathrm{ha})\end{array}$ & $\begin{array}{c}\text { LAI } \\
\left(\mathrm{m}^{2} / \mathrm{m}^{2}\right)\end{array}$ & $\begin{array}{l}\text { EW } \\
(\mathrm{mm})\end{array}$ \\
\hline Picea abies & $\mathrm{Pa} 39 \mathrm{a}$ & $46^{\circ} 34^{\prime} 47^{\prime \prime} \mathrm{N}$ & $5^{\circ} 52^{\prime} 37^{\prime \prime} \mathrm{E}$ & 970 & 10 & SE & $58(3) / 69$ & $30.2(2.5)$ & $45(4)$ & 414 & 6.1 & 65 \\
\hline \multirow[t]{4}{*}{ Norway spruce } & $\mathrm{Pa} 39 \mathrm{~b}$ & $46^{\circ} 31^{\prime} 00^{\prime \prime} \mathrm{N}$ & $6^{\circ} 03^{\prime} 44^{\prime \prime} \mathrm{E}$ & 1210 & 8 & W & $106(6) / 262$ & $23.6(2.2)$ & $44(5.1)$ & 746 & 6.8 & 109 \\
\hline & $\mathrm{Pa} 71$ & $47^{\circ} 00^{\prime} 33^{\prime \prime} \mathrm{N}$ & $4^{\circ} 07^{\prime} 06^{\prime \prime} \mathrm{E}$ & 600 & 20 & SE & $48(2) / 50$ & $27(1.2)$ & $41(3.7)$ & 460 & 7.4 & 149 \\
\hline & $\mathrm{Pa} 73$ & $45^{\circ} 35^{\prime} 12^{\prime \prime} \mathrm{N}$ & $6^{\circ} 47^{\prime} 23^{\prime \prime} \mathrm{E}$ & 1700 & 40 & NW & $185(12) / 209$ & $22(2.6)$ & $45(4.4)$ & 499 & 6.9 & 118 \\
\hline & $\mathrm{Pa} 88$ & $48^{\circ} 14^{\prime} 02^{\prime \prime} \mathrm{N}$ & $7^{\circ} 06^{\prime} 14^{\prime \prime} \mathrm{E}$ & 660 & 20 & SW & $89(2) / 92$ & $34.8(2.3)$ & $52(4.4)$ & 401 & 5.9 & 88 \\
\hline Abies alba & Aa 05 & $44^{\circ} 29^{\prime} 25^{\prime \prime} \mathrm{N}$ & $6^{\circ} 27^{\prime} 33^{\prime \prime} \mathrm{E}$ & 1360 & 30 & $\mathrm{NE}$ & $99(14) / 152$ & $28.3(2.7)$ & $50(7.1)$ & 375 & 7.7 & 190 \\
\hline \multirow[t]{5}{*}{ Silver fir } & Aa 07 & $44^{\circ} 42^{\prime} 36^{\prime \prime} \mathrm{N}$ & $3^{\circ} 57^{\prime} 57^{\prime \prime} \mathrm{E}$ & 1300 & 20 & W & $80(3) / 86$ & $25.7(1.5)$ & $58(5.8)$ & 315 & 5.9 & 92 \\
\hline & Aa 09 & $42^{\circ} 51^{\prime} 52^{\prime \prime} \mathrm{N}$ & $1^{\circ} 20^{\prime} 43^{\prime \prime} \mathrm{E}$ & 1100 & 66 & NW & $168(4) / 183$ & $25.1(3)$ & $44(4.1)$ & 427 & 6.6 & 80 \\
\hline & Aa 57 & $48^{\circ} 36^{\prime} 36^{\prime \prime} \mathrm{N}$ & $7^{\circ} 08^{\prime} 02^{\prime \prime} \mathrm{E}$ & 400 & 20 & NW & $54(4) / 60$ & $27.5(1.5)$ & $39(5)$ & 410 & 8.1 & 103 \\
\hline & Aa 63 & $45^{\circ} 26^{\prime} 51^{\prime \prime} \mathrm{N}$ & $3^{\circ} 31^{\prime} 39^{\prime \prime} \mathrm{E}$ & 1040 & 25 & SW & $100(14) / 225$ & $26.8(2.7)$ & $53(6.4)$ & 358 & 6.8 & 125 \\
\hline & Aa 68 & $47^{\circ} 56^{\prime} 01^{\prime \prime} \mathrm{N}$ & $7^{\circ} 07^{\prime} 31^{\prime \prime} \mathrm{E}$ & 680 & 45 & NW & $104(6) / 114$ & $29.3(2)$ & $53(5.9)$ & 322 & 6.2 & 60 \\
\hline
\end{tabular}

of the species-specific effects of the weather conditions on tree growth could help the foresters to direct the future forest management $[4,6]$.

In France, dendroecological studies of fir and spruce are scare $[4,9]$, and comparative analyses have been mainly carried out in French Alpine valleys [18, 19, 43]. This study led in high-elevation southern alpine stands (from 1400 to $2000 \mathrm{~m}$ a.s.1.) has revealed a species-specific pattern of climatic response with strong effects of local conditions such as aspects and altitude levels. Spruce is successively sensitive to current summer drought at the lower level, sensitive to the previous hot summer at the intermediate level, and sensitive to current cold summer at the upper level. Silver fir growth is highly influenced by the previous summer water balance, particularly on southern slopes. Ring-width is also enhanced by hot April temperatures in all stands and by hot February temperatures in northern slopes. Thus, at this regional alpine scale, fir appeared more thermophile than spruce. Summer weather conditions (water balance or temperature) also highly influenced both species, but the influence of the year preceding ring formation appeared higher for fir than for spruce.

The starting hypothesis of this study was that coniferous growth responses observed under high-elevation alpine weather conditions differ for stands sampled at lower altitudes and growing under more various ecological conditions. In this study, the relationships between tree growth and weather conditions were investigated in 11 natural mature silver fir and Norway spruce forests of the French Permanent Plot Network for the Monitoring of Forest Ecosystems network (RENECOFOR). The ecological conditions varied from low-elevation stands with mesic and fresh weather conditions to highelevation forests with very humid and cold weather conditions. The objectives of this study are: (1) to define the pattern of climatic response of each species, (2) to highlight the influence of local ecological conditions on climate response, and (3) to compare the response of silver fir and Norway spruce to climate. To precise the time of the transition phase between both components of the ring and to refine the tree-ring growth response to climate [28], an analysis of early- and latewood widths as separate variables of ring growth was also undertaken. Responses of total ring, early- and latewood ring-width variations to monthly climate were estimated by establishing the mean relationships between growth and climate through simple correlation analysis and bootstrapped response functions [26]. The response to climatic variability was also assessed by analysing pointer years which correspond to abrupt changes in growth pattern and reveal the tree-growth response to extreme climatic events [45]. Climatic variables were derived from an ecophysiological soil water balance model that calculates daily changes of soil water content and soil water deficit during phenologically defined periods of the growing season [23].

\section{MATERIALS AND METHODS}

\subsection{Studied sites}

The six silver firs and five Norway spruces stands were sampled in different French mountainous regions between $42^{\circ} 5^{\prime}$ and $48^{\circ} 4^{\prime} \mathrm{N}$ and $1^{\circ} 2^{\prime}$ and $7^{\circ} 1^{\prime} \mathrm{E}$. The mean slope was $30 \%$ (8 to $66 \%$ ) with altitude ranging from 400 to $1700 \mathrm{~m}$ a.s.l. (mean: $1004 \mathrm{~m}$ ) (Tab. I and Fig. 1). The pure sampled coniferous forests are composed of naturally regenerated even-aged stands from 48 to 185 years. The species composition of the ground vegetation and the pedological characteristics of two trenches were used to define the site type for each stand $[14,20]$. Extractable soil water was calculated for each stand according to textural properties, depth and coarse element percentages together with the rooting characteristics observed for each soil horizon [14]. Soil depth averaged $150 \mathrm{~cm}$ unless physical or pedological constraints to root penetration occurred. Soil types vary from brunisol with low maximum extractable soil water (EWm) $(65 \mathrm{~mm})$ to deep calcisol with high EWm $(190 \mathrm{~mm}$ ) (mean value: $107 \mathrm{~mm}$; French pedological reference) (Tab. I). Leaf area indices were estimated from an average value of leaf fall 1996 [12]. The range of LAI is 5.9 to $8.1 \mathrm{~m}^{2} / \mathrm{m}^{2}$ with a mean value of $6.8 \mathrm{~m}^{2} / \mathrm{m}^{2}$ (Tab. I). 


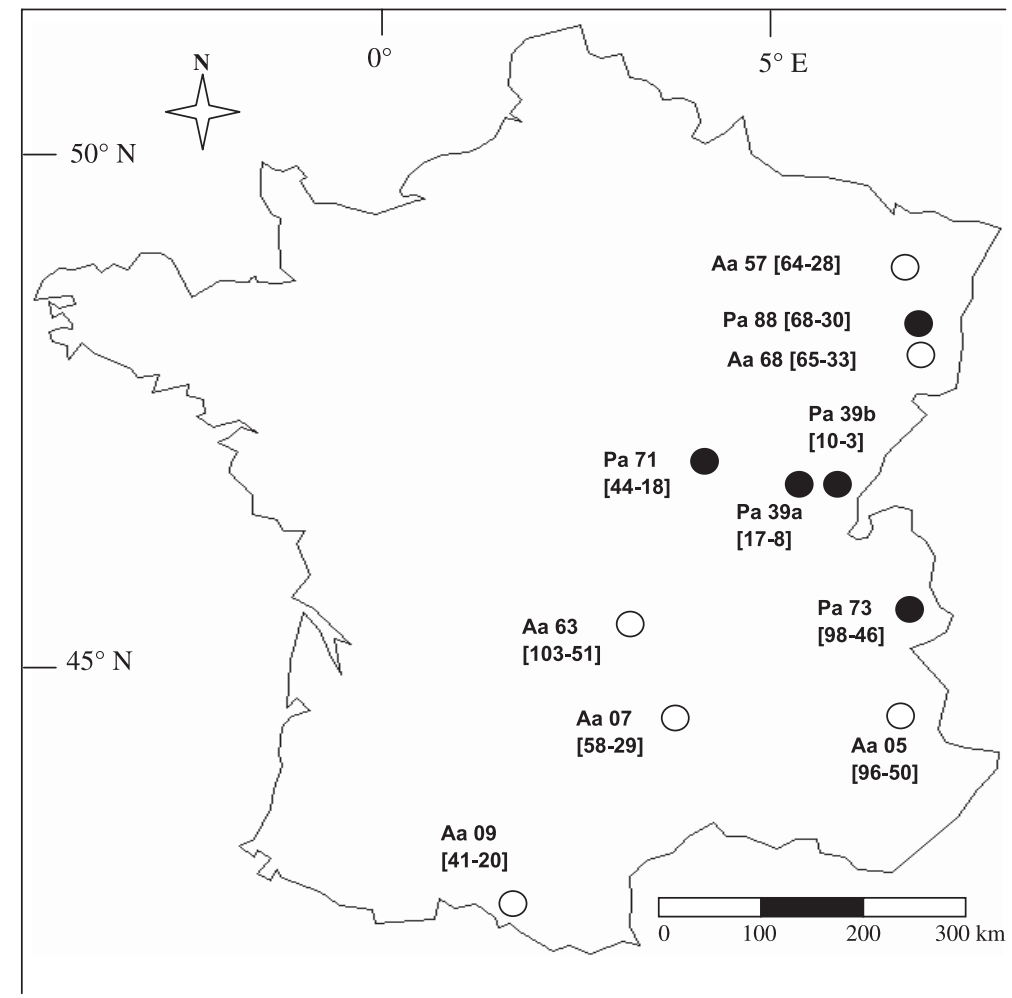

Figure 1. Location and mean annual soil water deficit duration (number of days of water deficit; first value in square brackets) and intensity (second value in square brackets) calculated for the 11 coniferous stands Aa: Abies alba; Pa: Picea abies (period 1961-1990).

\subsection{Measurements and computation of chronologies}

The 327 dominant trees were cored to the pith with an incremental borer at breast height ( 28 to 30 trees per plot; one core per tree). The 32109 rings were measured microscopically to an accuracy of nearest $0.01 \mathrm{~mm}$ for earlywood, latewood and total ring widths. Early- and latewood transitions within the annual rings were defined according to qualitative aspects (darkening) [40]. Each individual ring-width series were synchronized carefully after progressively detecting regional pointer years. The pointer years were defined for each ring component as those calendar years when at least $75 \%$ of the cross-dated trees presented the same sign of change: at least $10 \%$ narrower or wider than the previous year [4]. Absolute dating was checked by program COFECHA v6.06P [27] and computation of tree-ring chronologies was performed using the program ARSTAN v6.05P [17]. In a first step, a double-detrending process based on an initial negative exponential or linear regression followed by a fitting of a cubic smoothing spline with a base length of 20 years was applied for each raw measurement series. In a second step, the remaining autocorrelation was removed by autoregressive modelling. The residual series were averaged using a bi-weighted robust mean to create total ring, early- and latewood chronologies. Residual chronologies were used in response function and correlation analyses.

\subsection{Regional climate and soil water balance modelling}

Daily temperature $\left(\mathrm{Tmin}, \mathrm{Tmax} ;{ }^{\circ} \mathrm{C}\right)$, precipitation $(\mathrm{mm})$, cumulated global radiation $\left(\mathrm{J} . \mathrm{m}^{-2}\right)$, mean wind speed $\left(\mathrm{m} . \mathrm{s}^{-1}\right)$ and mean vapour pressure deficit $(\mathrm{Pa})$ from 22 meteorological stations of the Météo-France network were used to characterize each regional climate (Tab. II) and to quantify drought constraints in the forest stands. Meteorological stations were selected on their homogeneity and location to provide the most representative data of the local climatic contexts. High coniferous stands grow under very humid and cold climate. Total precipitation ranged between $790 \mathrm{~mm}$ (Abies alba 63, Aa63) and $1912 \mathrm{~mm}$ (Picea abies 39b, Pa39b) with an average value of $1318 \mathrm{~mm}$ (over 162 rainy days) (reference period 1961-1990) (Tab. II). About $40 \%$ of the total amount of precipitation falls during the growing season. Mean annual temperature averaged $8.4{ }^{\circ} \mathrm{C}$ $\left(5.1\right.$ to $11.8{ }^{\circ} \mathrm{C}$ ) with cold winters (mean: $1.7^{\circ} \mathrm{C}$ ) and a high number of frost days (mean yearly value: 104 days). Summers are fresh (mean: $16.3{ }^{\circ} \mathrm{C}$ ) and wet (about $100 \mathrm{~mm}$ per month), but the number of warm days is higher than 50 days for six stands.

A daily iterative soil water balance model [23] was used to quantify retrospectively drought intensity and duration in forest stands. To calculate the daily water balance, the site and stand parameters required are: maximum extractable soil water $\left(\mathrm{EW}_{\mathrm{M}}\right)$, growing season duration and leaf area index (LAI). The latter controls (i) global radiation extinction coefficient (k), (ii) stand transpiration; (iii) forest floor evapotranspiration; and (iv) rainfall interception [23]. A detailed parameterization was made at each sampled site according to the data presented in Table I. The length of the growing season was fixed to 365 days [31]. The model requires input climatic data such as rainfall and Penman daily potential evapotranspiration (PET). Under water stress conditions, the transpiration:PET ratio (T/PET) decreases linearly as soon as relative extractable water (REW) drops below a threshold of 0.4 (critical REW, REWc) of maximum extractable 
Table II. Mean climatic characteristics for each sampled stand. $N=$ Number of meteorological stations used. $\mathrm{Rd}$, rainy days $(P>0 \mathrm{~mm}) . \mathrm{Fd}$, number of frost days $\left(\operatorname{Tmin}<0{ }^{\circ} \mathrm{C}\right)$. $\mathrm{Wd}$, warm days (Tmax $>25^{\circ} \mathrm{C}$ ) (reference period: $\left.1961-1990\right)$.

\begin{tabular}{|c|c|c|c|c|c|c|c|c|c|}
\hline & \multirow[t]{2}{*}{ Site code } & \multirow[t]{2}{*}{$N$} & \multirow[t]{2}{*}{$\mathrm{Rd}$} & \multicolumn{2}{|c|}{ Precipitation (mm) } & \multicolumn{2}{|c|}{ Mean temperature $\left({ }^{\circ} \mathrm{C}\right)$} & \multirow[t]{2}{*}{$\mathrm{Fd}$} & \multirow[t]{2}{*}{$\mathrm{Wd}$} \\
\hline & & & & Year & May-Sept & Year & May-Sept & & \\
\hline Picea abies & $\mathrm{Pa} 39 \mathrm{a}$ & 3 & 167 & 1721 & 675 & 5.1 & 11.2 & 168 & 13 \\
\hline \multirow[t]{4}{*}{ Norway spruce } & $\mathrm{Pa} 39 \mathrm{~b}$ & 3 & 175 & 1912 & 745 & 5.1 & 11.2 & 168 & 13 \\
\hline & $\mathrm{Pa} 71$ & 2 & 194 & 1283 & 493 & 10.3 & 16 & 74 & 49 \\
\hline & $\mathrm{Pa} 73$ & 1 & 153 & 971 & 354 & 9.0 & 15.7 & 121 & 56 \\
\hline & $\mathrm{Pa} 88$ & 2 & 178 & 1142 & 504 & 10.2 & 17.1 & 82 & 58 \\
\hline Abies alba & Aa 05 & 2 & 97 & 837 & 362 & 10.0 & 16.6 & 104 & 61 \\
\hline \multirow[t]{5}{*}{ Silver fir } & Aa 07 & 3 & 138 & 1394 & 489 & 5.8 & 11.7 & 142 & 14 \\
\hline & Aa 09 & 2 & 163 & 1610 & 622 & 11.8 & 17.1 & 57 & 61 \\
\hline & Aa 57 & 3 & 181 & 973 & 401 & 9.1 & 15.6 & 81 & 33 \\
\hline & Аa 63 & 2 & 160 & 790 & 380 & 10.9 & 16.9 & 71 & 59 \\
\hline & Аa 68 & 2 & 180 & 1860 & 612 & 10.2 & 17.2 & 82 & 58 \\
\hline
\end{tabular}

water $\left(\mathrm{EW}_{\mathrm{M}}\right)$. REWc is basically a physiological threshold at which regulation of transpiration (T) begins to occur due to stomatal closure [23]. In the model, two stress indices are calculated if REW < REWc. The first index corresponds to the number of days of water stress, i.e. the number of days during which $\mathrm{REW}<0.4 \times \mathrm{EW}_{\mathrm{M}}$. The second indice is the water stress indice, which cumulates the difference between REW and REWc. Both indices can be monthly, seasonally or annually cumulated (Fig. 1). Mean soil water deficit durations range from less than 20 days for the two Picea abies $(\mathrm{Pa})$ stands sampled in the Jura Mountains ( $\mathrm{Pa} 39 \mathrm{a}$ and $\mathrm{Pa} 39 \mathrm{~b}$ ) to about 100 days for the Picea abies stand (Pa 73) and the two Abies alba (Aa) stands (Aa 05 and Aa 73).

\subsection{Response function analysis}

For each ring component, the effect of climate on growth was investigated in two steps. First, pointer years were compared with climatic data. Second, bootstrapped confidence intervals were used to estimate the significance of both correlation and response function coefficients [26]. Analyses were performed using 12 monthly water balance indices (Def) (May to October for the year and for the previous year) and 12 maximum or minimum monthly temperature (Tmax and Tmin from November to the previous growing season $(t-1)$ to October of the year in which the ring was formed) as regressors. The period of analysis varied from 1963-1994 to 1949-1994. The software package DENDROCLIM2002 computes the statistical significance of the coefficients by calculating 95\% quantile limits based on 1000 bootstrap re-sample of the data $[11,26]$. Thus, four analyses for each ring component (total ring, earlywood and latewood) have been performed for each stand. A cluster analysis was performed on response functions to detect stands which respond in a similar way to prevailing environmental factors. The (dis)similarity between sites was measured as Euclidean distance as: distance $(x, y)=$ $\{\Sigma i(x i-y i) 2\}^{1 / 2}$ and the hierarchy computed according to the Ward's method. This method uses an analysis of variance approach to evaluate the distances between clusters and attempts to minimize the Sum of Squares (SS) of any two (hypothetical) clusters that can be formed at each step.

\section{RESULTS}

\subsection{Analysis of pointer years}

For the period 1949-1994, the mean sensitivity (MS) of total ring width ranges from 0.162 to 0.265 (mean: 0.204 ) (Tab. III). MS is higher for latewood (mean: 0.307) than earlywood (mean: 0.249) suggesting that latewood is more sensitive to climate than earlywood. First-order autocorrelation coefficients averaged $0.809,0.725$ and 0.681 for total ring, earlywood and latewood, respectively. The high values observed for silver fir indicate a strong dependence of current growth on the previous year's growth.

The number of pointer years for total ring-width ranges from 4 to 21 (mean: 9) from the common period 1953 to 1994 (Tab. IV). Pointer years are more frequent in earlywood than in latewood for Picea abies stands (means 9 and 4, respectively) (data not shown). For Abies alba, pointer years tend to be more frequent in latewood. Strong and negative reactions were observed in 1986, 1962, 1956 and 1976 (Tab. IV). Significant growth decreases were also observed in 1973 (Picea abies) and 1991 (Abies alba). Common growth increases occurred in 1977, 1969 and 1955 for Abies alba and in 1963 for Picea abies.

There were many points of agreement between these pointer years and monthly minimum temperature and annual water stress intensity. Growth decreases observed in 1956 and 1986 were attributed to exceptional winter frosts (Tab. V). Depending on stands, these years were the first and/or the second coldest Februaries from 1953 to 1994. For these two years, mean minimum temperatures in February averaged $-8.5^{\circ} \mathrm{C}$ $\left(-0.5{ }^{\circ} \mathrm{C}\right.$ to $\left.-15.4{ }^{\circ} \mathrm{C}\right)$ which corresponded to a mean deviation of $-6.9{ }^{\circ} \mathrm{C}\left(-1.3^{\circ} \mathrm{C}\right.$ to $\left.-11.7^{\circ} \mathrm{C}\right)$ compared to the longterm monthly mean. Negative years 1962, 1991 and 1976 were mainly characterized by an important drought (Tab. V and Fig. 2). For these years, the annual water stress intensity was at $50 \%$ above normal. Positive years corresponded mainly to very moderate water stress (low drought index values). 
Table III. Chronology-statistics of unfiltred tree-ring series. IC: series intercorrelation. MS = Average mean sensitivity. AC = first-order autocorrelation. Values correspond to the reference period 1949-1994.

\begin{tabular}{|c|c|c|c|c|c|c|c|c|c|c|c|}
\hline & \multirow[b]{2}{*}{ Site code } & \multirow[b]{2}{*}{$\mathrm{Nb}$ of trees } & \multicolumn{3}{|c|}{ Total ring } & \multicolumn{3}{|c|}{ Earlywood } & \multicolumn{3}{|c|}{ Latewood } \\
\hline & & & IC & $\mathrm{AC}$ & MS & IC & $\mathrm{AC}$ & MS & IC & $\mathrm{AC}$ & MS \\
\hline Picea abies & $\mathrm{Pa} 39 \mathrm{a}$ & 30 & 0.657 & 0.742 & 0.209 & 0.598 & 0.691 & 0.241 & 0.427 & 0.608 & 0.319 \\
\hline \multirow[t]{5}{*}{ Norway spruce } & $\mathrm{Pa} 39 \mathrm{~b}$ & 30 & 0.631 & 0.824 & 0.164 & 0.613 & 0.776 & 0.195 & 0.312 & 0.683 & 0.239 \\
\hline & $\mathrm{Pa} 71$ & 30 & 0.745 & 0.703 & 0.265 & 0.690 & 0.659 & 0.294 & 0.630 & 0.500 & 0.421 \\
\hline & $\mathrm{Pa} 73$ & 29 & 0.548 & 0.899 & 0.169 & 0.491 & 0.869 & 0.204 & 0.316 & 0.761 & 0.298 \\
\hline & $\mathrm{Pa} 88$ & 30 & 0.532 & 0.702 & 0.217 & 0.491 & 0.587 & 0.281 & 0.36 & 0.606 & 0.327 \\
\hline & & & 0.623 & 0.774 & 0.205 & 0.577 & 0.716 & 0.243 & 0.409 & 0.632 & 0.321 \\
\hline Abies alba & Aa 05 & 30 & 0.625 & 0.906 & 0.162 & 0.457 & 0.641 & 0.207 & 0.493 & 0.640 & 0.260 \\
\hline \multirow[t]{6}{*}{ Silver fir } & Aa 07 & 30 & 0.728 & 0.807 & 0.181 & 0.660 & 0.750 & 0.206 & 0.591 & 0.735 & 0.269 \\
\hline & Aa 09 & 29 & 0.580 & 0.868 & 0.213 & 0.482 & 0.790 & 0.265 & 0.461 & 0.788 & 0.306 \\
\hline & Aa 57 & 30 & 0.616 & 0.770 & 0.213 & 0.477 & 0.678 & 0.276 & 0.351 & 0.658 & 0.327 \\
\hline & Аа 63 & 29 & 0.594 & 0.897 & 0.216 & 0.496 & 0.817 & 0.279 & 0.408 & 0.834 & 0.306 \\
\hline & Аa 68 & 30 & 0.709 & 0.780 & 0.232 & 0.643 & 0.713 & 0.289 & 0.488 & 0.683 & 0.310 \\
\hline & & & 0.642 & 0.838 & 0.203 & 0.536 & 0.732 & 0.254 & 0.465 & 0.723 & 0.296 \\
\hline
\end{tabular}

In all cases, growth decreases were higher for Abies alba than for Picea abies, suggesting a higher sensitivity to extreme conditions (frost and drought) for silver fir trees (Tab. IV). For the two coldest years 1956 and 1986, the growth reduction was about $60 \%$ higher for Abies alba than for Picea abies (means: $-38.8 \%$ and $-24.4 \%$, respectively). No obvious association with altitude has been observed.

For Picea abies, five of the six most frequent pointer years observed for earlywood are similar to those obtained for total ring width but growth variations are generally higher (5 to $25 \%$; mean: $15 \%$ ). Pointer years detectable for latewood are different from those defined for total ring and earlywood and only the negative year $1983(-43 \%)$ appeared common at three sites. For Abies alba, the negative years 1976 and 1986 are common to each ring component with comparable growth variations. The consecutive years 1955 (+) and 1956 (-) are common to total ring and earlywood whereas the years $1977(+)$ and $1962(-)$ are observed only in latewood and total ring. In all cases, growth variations tend to be more pronounced in each ring component than in total ring width.

\subsection{Correlation and response functions analyses}

For both species and each ring component, correlations were more frequent and bootstrapped coefficients were higher with the (Def-Tmax) combinations. The dominant climatic factor controlling early- and latewood widths of Picea abies is the current summer soil water deficit (July-August) (Tab. VI). This variable explains between 8 and $26 \%$ of the ring width variations (mean: 17\%). Earlywood is also influenced by maximum June temperature whereas temperatures in middle summer play a major role in latewood widths. Thus, high maximum temperature and drought in summer lead to narrow rings in Picea stands. The effects of the weather conditions for the other months are less frequent and significant. The response functions obtained for total ring series are quite similar to the results obtained for both components. High maximum August temperature and summer drought negatively influence total ring width (data not shown).

Patterns of response appear different for Abies alba stands. Previous water deficit in late summer and early autumn (Aug. to Oct.) negatively influence earlywood formation (Tab. VI). The weather conditions during this month explain between $7 \%$ to $27 \%$ of the earlywood width variations (mean: 18\%). The effects of February and June temperatures were observed in three stands. Latewood widths are strongly influenced by current early summer conditions through soil water deficits in June and July (negative effects) and temperatures. For the total ring width, climatic signal is also mostly related to drought and high previous late summer water deficits (Aug. to Oct.) which reduced ring widths at $70 \%$ of the sites (data not shown). The temperature signal is related to maximum values, and high temperatures in late winter (February or April) favour wide widths at $50 \%$ of the stands.

The cluster analysis separates both species but does not show any clear grouping either site characteristics (slope, exposure, altitude, soil water reserve) or sampling area (Fig. 3). Thus, the first group mainly corresponds to Abies alba stands with high sensitivity to previous conditions in the formation of ring, and the second group to Picea abies stands for which ring width depends mainly on current summer water stress.

\section{DISCUSSION}

The ordination of stands on the basis of response functions separates both species but does not show any clear grouping either site characteristics or sampling area. Thus, for each species, the high degree of similarity in growth variation between stands indicated similar growth responses to weather variations despite different environmental conditions. 
Table IV. Pointer years for total ring (period: 1953-1994). For each stand, pointer years were defined as those years when at least $75 \%$ of the cross-dated trees presented the same sign of change (at least $10 \%$ of relative growth variation between two consecutive years). The numbers indicate the relative growth variations (RGV \%) (-: negative pointer year). Pa and Aa: Picea abies and Abies alba. Pos.: positive pointer years (growth recovery); Neg.: negative pointer years (growth reduction).

\begin{tabular}{|c|c|c|c|c|c|c|c|c|c|c|c|c|c|}
\hline & \multicolumn{5}{|c|}{ Picea abies } & \multicolumn{6}{|c|}{ Abies alba } & \multicolumn{2}{|c|}{$N$} \\
\hline & Pa 39a & $\mathrm{Pa} 39 \mathrm{~b}$ & $\mathrm{~Pa} 71$ & $\mathrm{~Pa} 73$ & $\mathrm{~Pa} 88$ & Аа 05 & Аа 07 & Aa 09 & Aa 57 & Aa 63 & Aa 68 & $\mathrm{~Pa}$ & $\mathrm{Aa}$ \\
\hline 1953 & & & 32.8 & & & & & & & & & 1 & \\
\hline 1954 & & & -19.0 & & & & & & & & & 1 & \\
\hline 1955 & & 39.2 & & 37.7 & & & 39.1 & & 30.4 & 36.7 & & 2 & 3 \\
\hline 1956 & -25.0 & -23.9 & & & & & -39.6 & & & -35.6 & -58.5 & 2 & 3 \\
\hline 1957 & & & & & & & & & & & 76.4 & & 1 \\
\hline 1958 & & & & & & & & 48.3 & & & & & 1 \\
\hline 1959 & & & & & & & & & & 34.0 & -38.8 & & 2 \\
\hline 1960 & & & -24.6 & & & & & & & -24.6 & 58.8 & 1 & 2 \\
\hline 1961 & & & 34.1 & & & & & & 23.1 & & 50.5 & 1 & 2 \\
\hline 1962 & -26.5 & -25.1 & -28.0 & & -35.8 & -30.3 & -36.6 & & -24.5 & & -33.6 & 4 & 4 \\
\hline 1963 & 34.4 & 34.8 & 49.5 & & 43.6 & & & & & & & 4 & \\
\hline 1964 & & & & & -22.5 & 39.6 & 70.7 & & -23.1 & & & 1 & 3 \\
\hline 1965 & & & 22.6 & & & -21.4 & -18.7 & & & & & 1 & 2 \\
\hline 1966 & & & 25.6 & & & & & 31.0 & & & & 1 & 1 \\
\hline 1967 & & & -30.4 & & & & & & & & & 1 & \\
\hline 1968 & & & & & & & & & & & & & \\
\hline 1969 & & 36.4 & & & & 21.6 & 25.5 & & & 54.4 & & 1 & 3 \\
\hline 1970 & & & -20.1 & & & -23.5 & & & & & & 1 & 1 \\
\hline 1971 & & & & & & & & & & & & & \\
\hline 1972 & & & & & & & & & & & & & \\
\hline 1973 & -25.6 & & -22.6 & & -23.8 & & & & & & -27.7 & 3 & 1 \\
\hline 1974 & & & -32.9 & -20.1 & & & & & & & & 2 & \\
\hline 1975 & & & 74.5 & & & & & & & & & 1 & \\
\hline 1976 & -17.9 & & -56.9 & & & & & & -42.6 & & -41.9 & 2 & 2 \\
\hline 1977 & & 24.4 & & 31.0 & & 26.9 & 23.9 & & 72.3 & 28.1 & 110.2 & 2 & 5 \\
\hline 1978 & & & 108.5 & & & & & & & & & 1 & \\
\hline 1979 & & & & & & & & & & & & & \\
\hline 1980 & & & 31.3 & -16.6 & & & & & & & & 2 & \\
\hline 1981 & 32.7 & 27.7 & & & & & & & & & & 2 & \\
\hline 1982 & & & & & & & & & & & & & \\
\hline 1983 & -23.3 & & -35.9 & & & & & & & & & 2 & \\
\hline 1984 & & & & -18.8 & & -19.5 & & & & & & 1 & 1 \\
\hline 1985 & & & & & & 21.9 & & & & & & & 1 \\
\hline 1986 & -25.2 & -22.6 & -25.3 & & & -31.5 & -41.4 & -37.1 & & -31.3 & -35.6 & 3 & 5 \\
\hline 1987 & & & & & & 21.9 & & & & & & & 1 \\
\hline 1988 & & & 45.3 & & & & & & 38.4 & & & 1 & 1 \\
\hline 1989 & & & & & & & & & & & -21.8 & & 1 \\
\hline 1990 & & & -23.8 & & -23.8 & & & & & & & 2 & \\
\hline 1991 & & & & -20.8 & & -17.3 & & & -24.4 & & -20.0 & 1 & 3 \\
\hline 1992 & & & 33.5 & & & & & & & & & 1 & \\
\hline 1993 & 56.1 & & & & 43.7 & 29.9 & & 43.4 & & & & 2 & 2 \\
\hline 1994 & & & & & & & & & & & & & \\
\hline Pos: & 3 & 5 & 10 & 2 & 2 & 6 & 4 & 3 & 4 & 4 & 4 & & \\
\hline Freq: & $7 \%$ & $12 \%$ & $24 \%$ & $5 \%$ & $5 \%$ & $14 \%$ & $10 \%$ & $7 \%$ & $10 \%$ & $10 \%$ & $10 \%$ & & \\
\hline RGV\% & 41.1 & 32.5 & 45.8 & 34.3 & 43.7 & 26.9 & 39.8 & 40.9 & 41.1 & 38.3 & 74.0 & & \\
\hline Neg: & 6 & 3 & 11 & 4 & 4 & 6 & 4 & 1 & 4 & 3 & 8 & & \\
\hline Freq: & $14 \%$ & $7 \%$ & $26 \%$ & $10 \%$ & $10 \%$ & $14 \%$ & $10 \%$ & $2 \%$ & $10 \%$ & $7 \%$ & $19 \%$ & & \\
\hline RGV\% & -23.9 & -23.8 & -29.0 & -19.1 & -26.5 & -23.9 & -34.1 & -37.1 & -28.6 & -30.5 & -34.7 & & \\
\hline
\end{tabular}


Table V. Mean weather conditions for the most frequent pointer years (total ring, period 1953-1994). RGV\%: relative growth variations (-: negative pointer year). Temp: mean minimum February temperature $\left({ }^{\circ} \mathrm{C}\right)$; Drought indice: annual water stress indice. $\mathrm{Ltm}=\mathrm{Long}$ term mean (1953-1994).

Picea abies ( $n=5$ stands; 149 trees)

Temp. (Ltm: $\left.-1.04(3.0)^{\circ} \mathrm{C}\right) \quad$ Drought indice (Ltm: $20.8(23.3)$ )

\begin{tabular}{cccccccccc} 
Year & RGV\% & Mean & Std & Min & Max & Mean & Std & Min & Max \\
\hline 1986 & -24.4 & -6.2 & 2.52 & -9.0 & -0.5 & 23.7 & 21.9 & 0.0 & 55.6 \\
1976 & -38 & -0.6 & 1.21 & -2.7 & 0.9 & 49.3 & 32.5 & 14.2 & 79.7 \\
1973 & -24 & -2.4 & 2.08 & -6.0 & -0.3 & 13.0 & 17.1 & 0.0 & 40.5 \\
1963 & +40.6 & -6.3 & 2.00 & -9.1 & -2.1 & 1.9 & 3.3 & 0.0 & 7.7 \\
1962 & -28.9 & -2.4 & 1.83 & -5.4 & 0.0 & 60.1 & 34.5 & 28.9 & 103.5 \\
1956 & -24.4 & -11.6 & 0.02 & -11.6 & -11.5 & 0.0 & 0.0 & 0.0 & 0.0 \\
\hline
\end{tabular}

Abies alba ( $n=6$ stands; 178 trees $)$

\begin{tabular}{lccccccccc} 
& \multicolumn{3}{c}{ Temp. $\left(\mathrm{Ltm}:-1.41(3.2){ }^{\circ} \mathrm{C}\right)$} & \multicolumn{3}{c}{ Drought indice (Ltm: $34.2(25.3))$} \\
\cline { 2 - 9 } Year & RGV\% & Mean & Std & Min & Max & Mean & Std & Min & Max \\
\hline 1991 & -20.6 & -3.9 & -6.0 & -0.5 & 2.2 & 50.3 & 19.8 & 12.2 & 66.6 \\
1986 & -35.4 & -5.8 & -9.0 & -0.5 & 3.3 & 50.4 & 17.8 & 19.1 & 73.8 \\
1977 & +52.3 & 1.6 & -2.3 & 3.8 & 2.3 & 4.3 & 6.7 & 0.0 & 14.5 \\
1976 & -45 & -0.7 & -2.7 & 0.9 & 1.4 & 58.8 & 20.2 & 26.3 & 84.3 \\
1969 & +33.9 & -3.8 & -8.4 & -1.3 & 2.6 & 25.2 & 21.8 & 0.1 & 58.4 \\
1962 & -31.3 & -2.4 & -5.3 & 0.0 & 2.0 & 75.3 & 17.1 & 55.8 & 100.5 \\
1956 & -44.5 & -11.6 & -15.4 & -8.3 & 2.7 & 9.6 & 8.9 & 0.0 & 19.0 \\
1955 & +35.4 & -1.4 & -2.4 & 0.3 & 1.5 & 43.5 & 42.3 & 0.1 & 84.7 \\
\hline
\end{tabular}

Both pointer years and response functions showed that soil water deficit is the most important growth-limiting factor for Picea and Abies stands, in spite of high mean annual precipitation regimes and well-distributed throughout the year. The studied stands represent "moist and warm" sites sampled at low altitude (mean: $1004 \mathrm{~m}$ a.s.l.). Geographical location ranges between $42^{\circ} 5^{\prime}$ and $48^{\circ} 4^{\prime}$ which correspond to southwestern coniferous forests in Europe. Thus, our results are consistent with earlier findings [19] at the lowest levels in French Alps, and with the more general pattern of the annual growth of conifers in low latitudes or altitudes which focus the major role of summer water balance in determining growth rates $[5,9,21,34,39,49]$. In more central or northern European regions, numerous studies showed that the strength of direct and unique association between temperature and growth increased with increasing latitude and/or elevation $[35,36,38,48]$. The importance of drought in determining growth is particularly obvious for the two narrow tree-ring widths 1962 and 1976. In France, it has been shown [13] that those years were among the driest years observed in northeastern France over the last 50 years. Similarly in Geneva, 1962 was the driest year recorded from 1826-1987 [43]. Winter temperatures play also an important role in determining growth, particularly for extremely thin tree-ring widths. High winter temperatures generally promote growth, but extreme frosts cause substantial growth reductions for both species (negative pointer years in 1986 and 1956).
The pointer years 1956, 1962, 1976 and 1986 appear to be among the most geographically extended pointer years throughout Europe and in a wide range of taxa [45]. Those years have been observed for numerous altitude coniferous stands in the French Jura and in Switzerland [10,39], in the Vosges Mountains [3,4], in the French and Italian Alps [19, 22, 43], in Belgium Ardenne [37], in Czech Republic [44] and in Germany [49]. The dry years 1962 and 1976 have been also observed in broadleaved stands in different French areas [7, 29,30]. Both coniferous species have reacted strongly to those years, but Abies was more affected than Picea confirming a higher sensitivity to extreme frosts or drought for that species. From an ecophysiological point of view, silver fir exhibits a marked "avoidance" strategy characterized by an early response to drought (rapid stomatal closure with increasing soil water content depletion) [25]. A browning of older needles has been also observed in natural silver fir stands subjected to drought. Such an observation may partly explain the importance of climatic after-effects observed for this species.

Current summer water stress controls the growth of both species, but Abies alba appears to be more dependent on weather conditions during the previous growing season than Norway spruce. For Abies alba, temperatures during the first part of the growing season, as well as the water supply of the previous year are keys for the production of earlywood. Thus, earlywood formation is mainly controlled by lagged climatic effects, after which the current early summer water supply 

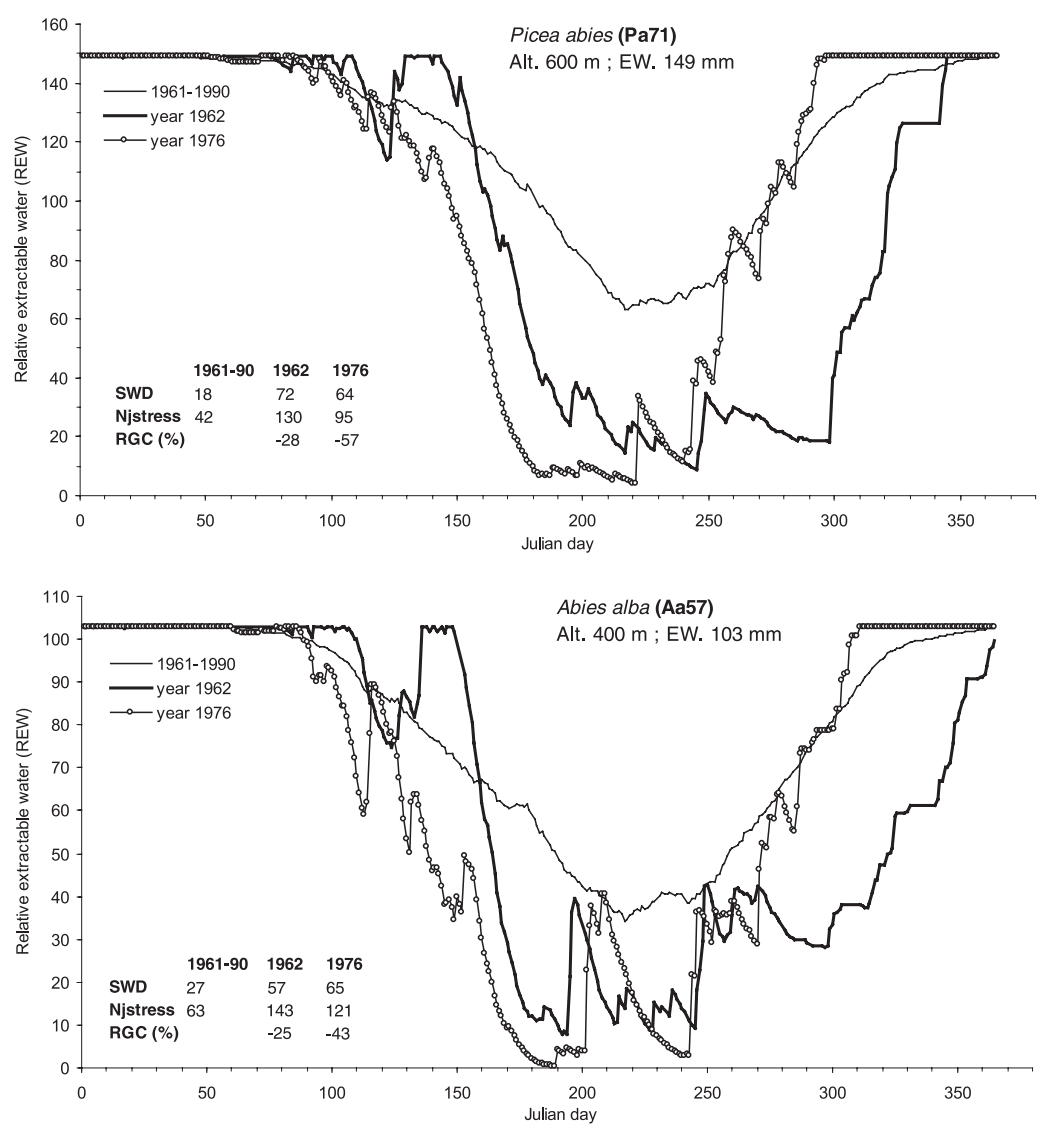

Figure 2. Time-course of relative extractable water in the soil simulated with the daily water balance model during the negative pointer years 1962 (thick line) and 1976 (circles) for the stands Pa71 and Aa57 (see Fig. 1 for the geographical location of each stand). The thin line represents the average time-course of the relative extractable water in the soil for the period 1961-1990. EW = maximum soil water reserve (mm). Njstress: number of days of water stress. SWD: soil water deficit indice (see text for details). RGC\%: relative growth changes for total ring.

influences mainly latewood width. The role of weather conditions in previous autumn in the seasonal dynamic of carbohydrate storage or root elongation could explain those results [1]. These findings are consistent with those obtained for silver fir stands growing between 550 and $1350 \mathrm{~m}$ a.s.1. in the Vosges Mountains [5]. Summer temperatures and water balance in August are especially important. High water deficit in August in a given year leads to significant repercussions for the six following years. Similar results have been obtained in the Jura Mountains, where the most crucial month was September, instead of August, probably because of the more southerly location of the Jura Mountains [5, 9]. As observed in our study, high values of February temperature promote growth in both contexts. If no correlation with winter temperature has been observed for the sampled spruce trees, February temperature still seems to be an important factor for coniferous stands; a significant effect of temperature during this month was also found in the tree-ring indices of numerous Pinus, Abies or Picea species irrespective of geographical locality, elevation, or site conditions. Because photosynthesis is possible for Abies alba in winter [24], high temperatures during the winter period could play a positive role in improving carbohydrate storage and growth of the following year. Warming in winter could also decrease embolism [33], advance leaf unfolding and lengthen the growing season the following year [31]. Different process-based growth models which incorporate low-temperature effects indicate that winter temperatures should be incorporated into climate change models designed to simulate tree growth and distribution [8].

All growth indices of Picea abies are highly related to summer water deficits during the current growing season which is consistent with studies dealing with the effects of drought on the ecophysiological feature of this species [32]. The current June temperature also affects the earlywood width, while the latewood responds to the current summer temperatures. In our studied stands, no common relationship between previous weather conditions, winter temperatures and the growth of Norway spruce was found. The effect of current summer temperature was also observed in Finland [35, 36] and in Germany [50] where summer drought influenced both latewood width and cell wall proportion in latewood.

In conclusion, annual growth variations of Abies alba and Picea abies are quite different. Moreover, the spatial relationship between growth and weather variation seems to be less 
Dendroclimatology of Abies alba and Picea abies

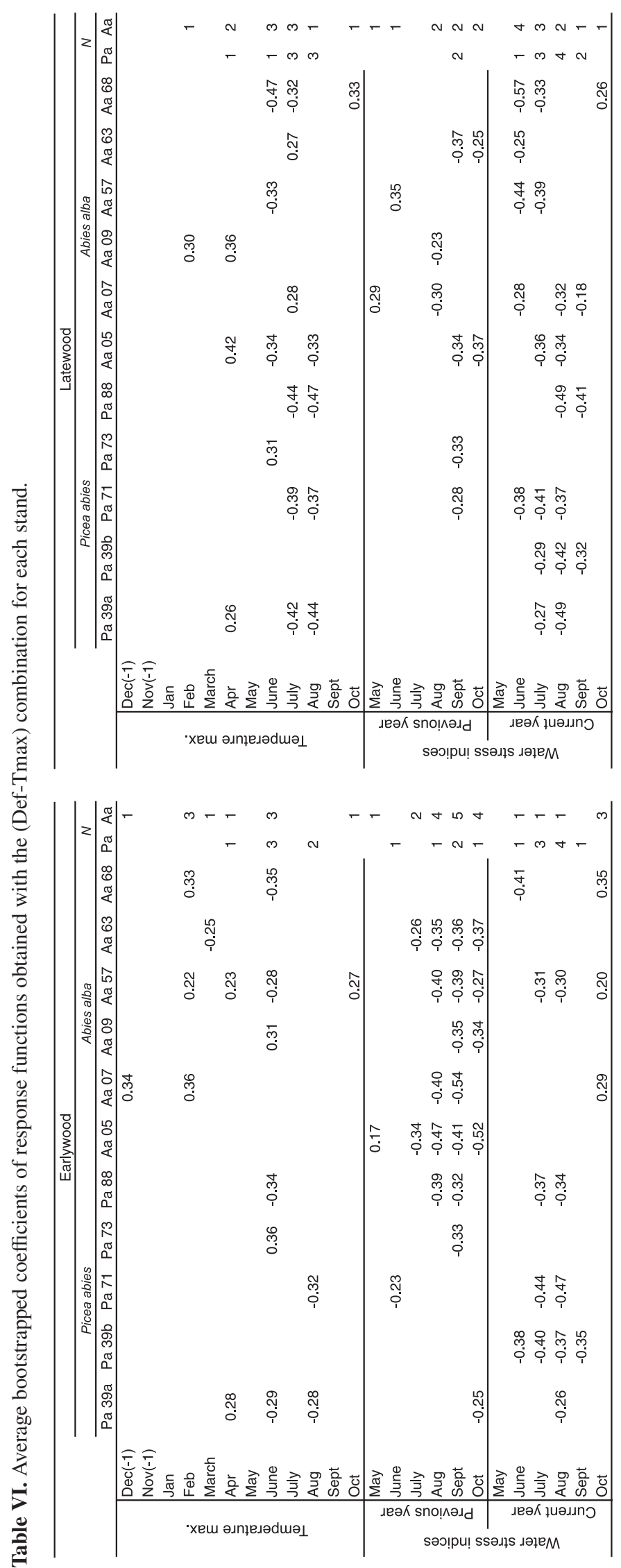




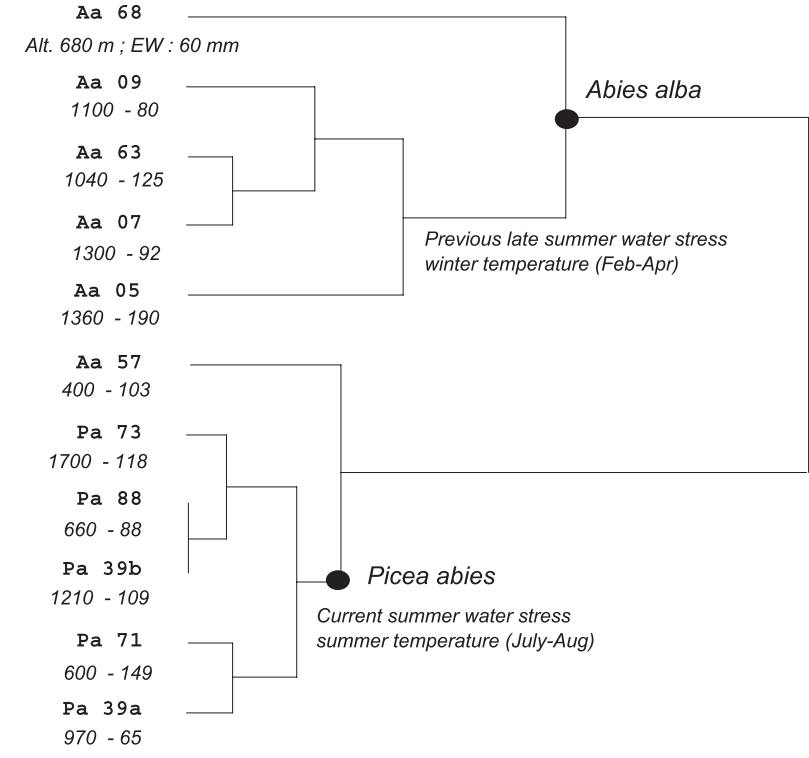

Figure 3. Group average dendrogram of earlywood tree-ring-indices using Euclidean distances based on response functions (DeficitTmax). (type of hierarchy algorithm used: Ward's methods). Alt: Altitude (m). EW: Maximum extractable soil water $(\mathrm{mm})$.

important than temporal variations for each species. The same parameter during the same month affected the variation in annual growth in all sites in a relatively uniform manner. Spruce growth mainly depends on current conditions whereas fir variation is attributed to lagged climatic effects. Changes in frequency of extreme years of drought and in winter temperature regime, as predicted consequences of a climate change, may shift the dynamics of growth more or less abruptly in favour of the less sensitive tree species.

Acknowledgements: I thank the European Commission, the French Agricultural Ministry The French National Institute of Forest Research and The French National Forest Office for providing funds to conduct this research (contract DG VI, No. 9760FR0030). I also thank Météo France for their helpful technical assistance for the selection of the meteorological stations. I thank Christophe Coudun and Tim Randle from the Centre for Terrestrial Carbon Dynamics (CTCD, United Kingdom) for the English corrections of the manuscript.

\section{REFERENCES}

[1] Barbaroux C., Bréda N., Contrasting distribution and seasonal dynamics of carbohydrate reserves in stem wood of adult ring-porous sessile oak and diffuse-porous beech trees, Tree Physiol. 22 (2002) $1201-1210$.

[2] Becker M., Transpiration et comportement vis-à-vis de la sécheresse de jeunes plants forestiers (Abies alba Mill., Picea abies L. Karsten, Pinus nigra Arn. ssp. laricio Poiret, Pinus strobus L.), Ann. Sci. For. 27 (1970) 401-420.

[3] Becker M., Bilan de santé actuel et rétrospectif du sapin (Abies alba Mill.) dans les Vosges. Étude écologique et dendrochronologique, Ann. Sci. For. 44 (1987) 379-402.
[4] Becker M., The role of climate on present and past vitality of silver fir forests in the Vosges Mountains of northeastern France, Can. J. For. Res 19 (1989) 1110-1117.

[5] Becker M., Bert D., Landmann G., Lévy G., Rameau J.C., Ulrich E., Growth and decline symptoms of silver fir and Norway spruce in northeastern France: relation to climate nutrition and silviculture, in: Forest decline and air pollution effects in the French mountains, 1995, pp. 120-142.

[6] Becker M., Landmann G., Lévy G., silver fir decline in the Vosges Mountains (France): role of climate and silviculture, Water Air Soil Pollut. 48 (1989) 77-86.

[7] Becker M., Nieminen T.M., Geremia F., Short-term variations and long-term changes in oak productivity in northeastern France. The role of climate and atmospheric $\mathrm{CO}_{2}$, Ann. Sci. For. 51 (1994) 477-492.

[8] Bergh J., Mcmurtrie R.E., Linder S., Climatic factors controlling the productivity of Norway spruce: A model-based analysis, For. Ecol. Manage. 110 (1998) 127-139.

[9] Bert D., Impact of ecological factors climatic stresses and pollution on growth and health of silver fir (Abies alba Mill.) in the Jura mountains: an ecological and dendrochronological study, Acta Oecol. 14 (1993) 229-246.

[10] Bert D., Becker M., Vitalité actuelle et passée du sapin (Abies alba Mill.) dans le Jura. Étude dendroécologique, Ann. Sci. For. 47 (1990) 395-412.

[11] Biondi F., Waikul K., Dendroclim2002: a C++ program for statistical calibration of climate signals in tree-ring chronologies, Comput. Geosci. 30 (2004) 303-311.

[12] Bréda N., Ground-based measurements of leaf area index: a review of methods, instruments and current controversies, J. Exp. Bot. 54 (2003) 2403-2417.

[13] Bréda N., Granier A., Aussenac G., La sécheresse de 2003 dans le contexte climatique des 54 dernières années: analyse écophysiologique et influence sur les arbres forestiers, Rev. For. Fr. 51 (2004) $109-131$.

[14] Brêthes A., Ulrich E., Caractéristiques pédologiques des 102 peuplements du réseau, Office National de Forêts, Département des Recherches Techniques, 1997.

[15] Buchmann N., Plant ecophysiology and forest response to global change, Tree Physiol. 22 (2002) 1177-1184.

[16] Ciais P., Reichstein M., Viovy N., Granier A., Ogee J., Allard V., Aubinet M., Buchmann N., Bernhofer C., Carrara A., Chevallier F., De Noblet N., Friend A.D., Friedlingstein P., Grunwald T., Heinesch B., Keronen P., Knohl A., Krinner G., Loustau D., Manca G., Matteucci G., Miglietta F., Ourcival J.M., Papale D., Pilegaard K., Rambal S., Seufert G., Soussana J.F., Sanz M.J., Schulze E.D., Vesala T., Valentini R., Europe-wide reduction in primary productivity caused by the heat and drought in 2003, Nature 437 (2005) 529-533.

[17] Cook E.R., A time series analysis approach to tree-ring standardization, Lamont-Doherty Geological Observatory, New York, 1985.

[18] Desplanque C., Rolland C., Michalet R., Dendroécologie comparée du sapin blanc (Abies alba) et de l'épicea commun (Picea abies) dans une vallée alpine de France, Can. J. For. Res 28 (1998) $737-748$

[19] Desplanque C., Rolland C., Schweingruber F.H., Influence of species and abiotic factors on extreme tree ring modulation: Picea abies and Abies alba in Tarentaise and Maurienne (French Alps), Trees 13 (1999) 218-227.

[20] Dobremez J.F., Camaret S., Bourjot L., Ulrich E., Brêthes A., Coquillard P., Dumé G., Dupouey J.L., Forgeard F., Gauberville C., 
Gueugnot J., Picard J.F., Savoie J.M., Schmitt A., Timbal J., Touffet J., Trémolières M., Inventaire et interprétation de la composition floristique de 101 peuplements du réseau, Office National de Forêts, Département des Recherches Techniques, 1997.

[21] Eckstein D., Krause C., Bauch J., Dendroecological investigation of spruce trees (Picea abies (L.) Karst) of different damage and canopy classes, Holzforschung 43 (1989) 411-417.

[22] Gandolfo C., Tessier L., Analyse dendroécologique sur des sapins (Abies alba Mill.) et des épicéas (Picea abies (L.) Karst.) de différents classes de défoliation dans la forêt de Vigo di Ton (Trento Italie), Ann. Sci. For. 51 (1994) 391-406.

[23] Granier A., Bréda N., Biron P., Villette S., A lumped water balance model to evaluate duration and intensity of drought constraints in forest stands, Ecol. Model. (1999) 269-283.

[24] Guehl J.M., Étude comparée des potentialités hivernales d'assimilation carbonée de trois conifères de la zone tempérée (Pseudotsuga menziesii Mirb., Abies alba Mill. et Picea excelsa Link), Ann. Sci. For. 42 (1985) 23-38.

[25] Guicherd P., Water relations of European silver fir (Abies alba Mill.) in 2 natural stands in the French Alps subject to constrating climatic conditions, Ann. Sci. For. 51 (1994) 599-611.

[26] Guiot J., The bootstrapped response function, Tree-Ring Bull. 51 (1991) 39-41.

[27] Holmes R.L., Computer-assisted quality control in tree-ring dating and measurements, Tree-Ring Bull. 43 (1983) 69-78.

[28] Lebourgeois F., Climatic signals in earlywood, latewood and total ring width of Corsican pine from western France, Ann. For. Sci. 57 (2000) 155-164.

[29] Lebourgeois F., Bréda N., Ulrich E., Granier A., Climate-treegrowth relationships of European beech (Fagus sylvatica L.) in the French Permanent Plot Network (RENECOFOR), Trees 19 (2005) 385-401.

[30] Lebourgeois F., Cousseau G., Ducos Y., Climate-tree-growth relationships of Quercus petraea Mill. stand in the Forest of Berce (Futaie des Clos, Sarthe, France), Ann. For. Sci. 61 (2004) 361-372.

[31] Lebourgeois F., Differt J., Granier A., Bréda N., Ulrich E., Premières observations phénologiques des peuplements du réseau national de suivi à long terme des écosystèmes forestiers (RENECOFOR), Rev. For. Fr. 54 (2002) 407-418.

[32] Lu P., Biron P., Bréda N., Granier A., Water relations of adult Norway spruce (Picea abies (L.) Karst.) under soil drought in the Vosges mountains: water potential stomatal conductance and transpiration, Ann. Sci. For. 52 (1995) 117-129.

[33] Maherali H., Pocknan W.T., Jackson R.B., Adaptive variation in the vulnerability of woody plants to xylem cavitation, Ecology 85 (2004) 2184-2199.

[34] Mäkinen H., Nojd P., Kahle H.P., Neumann U., Tveite B., Mielikainen K., Rohle H., Spiecker H., Radial growth variation of Norway spruce (Picea abies (L.) Karst.) across latitudinal and altitudinal gradients in central and northern Europe, For. Ecol. Manage. 171 (2002) 243-259.
[35] Mäkinen H., Nojd P., Mielikainen K., Climatic signal in annual growth variation of Norway spruce (Picea abies) along a transect from central Finland to the Arctic timberline, Can. J. For. Res 30 (2000) 769-777.

[36] Miina J., Dependence of tree-ring, earlywood and latewood indices of Scots pine and Norway spruce on climatic factors in eastern Finland, Ecol. Model. 132 (2000) 259-273.

[37] Misson L., Nicault A., Guiot J., Effects of different intensities on drought response in Norway spruce (Picea abies (L.) Karst.), For. Ecol. Manage. 183 (2003) 47-60.

[38] Neumann U., Rohle H., The weather-dependent annual radial increment of Norway spruce (Picea abies [L.] Karst.) in mountainous regions of Saxony, Forstwiss. Centr. 120 (2001) 277-287.

[39] Neuwirth B., Esper J., Schweingruber F.H., Winiger M., Site ecological differences to the climatic forcing of spruce pointer years from the Lötschental, Switzerland, Dendrochronologia 21 (2004) 69-78.

[40] Park Y.I., Dallaire G., Morin H., A method for multiple intra-ring demarcation of coniferous trees, Ann. For. Sci. 63 (2006) 9-14.

[41] Pinto P.E., Gegout J.C., Assessing the nutritional and climatic response of temperate tree species in the Vosges mountains, Ann. For. Sci. 62 (2005) 761-770

[42] Rolland C., Tree-ring and climate relationships for Abies alba in the internal Alps, Tree-ring Bull. 53 (1993) 1-11.

[43] Rolland C., Desplanque C., Michalet R., Schweingruber F.H., Extreme tree rings in (spruce Picea abies [L.] Karst.) and fir (Abies alba Mill.) stands in relation to climate, site and space in the southern French and Italian Alps, Arct. Antarc. Alp. Res. 32 (2000) 1-13.

[44] Sander C., Eckstein D., Kyncl J., Dobry J., The growth of spruce (Picea abies (L.) Karst) in the Krkonose (Giant) Mountains as indicated by ring width and wood density, Ann. Sci. For. 52 (1995) $401-410$.

[45] Schweingruber F.H., Nogler P., Synopsis and climatological interpretation of Central european tree-ring sequences, Bot. Helv. 2 (2003) 125-143.

[46] Tardif J., Camarero J.J., Ribas M., Gutierrez E., Spatio-temporal variability in tree growth in the Central Pyrenees: Climatic and site influences, Ecol. Monogr. 73 (2003) 241-257.

[47] Thomas A.L., Gegout J.C., Landmann G., Dambrine E., King D., Relation between ecological conditions and fir decline in a sandstone region of the Vosges Mountains (northeastern France), Ann. For. Sci. 59 (2002) 265-273.

[48] Waldner P.O., Schweingruber F.H., Temperature influence on decennial tree-ring width and density fluctuations of subalpine and boreal conifers in western Europe since 1850 A.D., Dendrochronologia 14 (1996) 127-151.

[49] Wilson R., Hopfmueller M., Dendrochronological investigations of Norway spruce along an elevation transect in the Bavarian Forest, Germany, Dendrochronologia 19 (2001) 67-79.

[50] Wimmer R., Grabner M., A comparison of tree-ring features in Picea abies as correlated with climate, IAWA J. 21 (2000) 403-416. 